Argyro Fassoulaki MD PhD DEAA,

Constantine Sarantopoulos MD DEAA, Marianna Zotou MD, Dimitra Papoulia MD

\title{
Preemptive opioid analgesia does not influence pain after abdominal hysterectomy
}

\begin{abstract}
Opioid administration before surgical stimulus may reduce or prevent subsequent pain. We studiued the effect of timing of opioid administration on the pain-related behaviour afier abdominal hysterectomy. Eighty-five patients scheduled for abdominal hysterectomy were blindly randomized to receive fentanyl $10 \mu \mathrm{g} \cdot \mathrm{kg}^{-1}$ before induction of anaesthesia (FA), after peritoneal incision (FB) or after removal of the uterus (FC). or sufentanil I $\mu \mathrm{g} \cdot \mathrm{kg}^{-1}$ before induction of anaesthesia (SA) or after peritoneal incision (SB) respectively. All patients received a standard postoperative analgesic regimen. The time from skin closure to the first analgesic request was recorded. Pain was assessed using the VAS and a verbal rating score (VSR $I=$ no pain to $6=$ intolerable pain) every $30 \mathrm{~min}$ until patients asked for the first analgesic, and $24 \mathrm{hr}$ postoperatively. The times from skin closure to the first analgesic request did not differ among the five groups. The VAS scores using the twoway ANOVA with repeated measurements differed among the five groups $(F=4.046, d f=4,213, P<0.005)$. The VAS scores with one-way ANOVA differed among the five groups 30 min postoperatively $(F=4.542, d f=4,58, P<0.003)$, being higher in the $F A(6.5 \pm 1.8)$ and $S A(5.9 \pm 2.1)$ groups than in the $F C(3.2 \pm 2.5)$ group, and at 120 min postoperatively $(F=3.217, d f=4,18, P<0.05)$, being higher in the $F A$ than in the $F B$ group ( $6.1 \pm 1.5$ and $2.6 \pm 1.9$ respectively). The VRS scores did not differ among the FA, FB, FC, $S A$ and $S B$ groups at any time. This study failed to demonstrate a preemptive effect of systemic administration of fentanyl or sufentanil in the doses tested.
\end{abstract}

\section{Key words}

ANALGESIA: postoperative;

ANALGESICS, OPIOIDS: fentanyl, sufentanil;

PAIN: preemptive analgesia.

From the Department of Anaesthesia, St Savas Hospital, 171 Alexandras Ave, 11522 Athens, Greece.

Address correspondence to: Dr. A. Fassoulaki, 57-59

Raftopoulou Street, 11744 Athens, Greece.

Presented in part to the Anaesthetic Research Society, London, November 1993.

Accepted for publication 15th September, 1994.
L'administration d'un morphinique avant le stimulus chirurgical peut diminuer ou prévenir la douleur quil déclenche. Nous avons étudié l'effet chronologique de l'administration d'un morphinique sur le comportement douloureux après une hystérectomie abdominale. Quatre-vingt-cinq patientes programmées pour une hystérectomie abdominale sont réparties au hasard et en aveugle pour recevoir respectivement 10 $\mu \mathrm{g} \cdot \mathrm{kg}^{-1}$ de fentanyl avant l'induction de l'anesthésie (groupe $F A$ ), après lincision du péritoine (groupe $F B$ ) ou après lablation de liutérus (FC), ou du sufentanil $1 \mu \mathrm{g} \cdot \mathrm{kg}^{-1}$ avant linduction de l'anesthésie (SA) ou après lincision péritonéale (SB). Après lintervention toutes les patientes reçoivent une médication analgésique standard. Le délai entre la fermeture de la peau et la première demande d'analgésique est enregistré. La douleur est évaluée sur une échelle visuelle analgique (EVA) et verbale simple (EVS) (cote évaluation verbale: $1=$ pas de douleur à $6=$ douleur intolérable) aux trente minutes jusqu'au moment de la réclamation par la patiente d'un premier analgésique et pendant les 24 h qui suivent lintervention. Le délai entre la fermeture de la peau et le premier analgésique n'est pas différent entre les cinq groupes. Les scores de l'EVA analysés par ANOVA à deux voies sur des mesures répétées différent entre les cinq groupes $(F=4,046, d f=4,213, P<0,005)$. Les scores de l'EVA avec l'ANOVA simple différent entre les cinq groupes 30 min après lintervention $(F=4,542$, df $=$ 4, 58, $P<0,003)$, étant plus élevés dans les groupes $F A(6,5$ $\pm 1,8)$ et $S A(5,9 \pm 2,1)$ comparativement aux groupes $F C$ $(3,2 \pm 2,5)$. Ils different aussi à 120 min après lintervention $(F=3,217, d f=4,18, P<0,05)$, en étant plus élevés dans le groupe $F A$ que dans le groupe $F B(6,1 \pm 1,5$ et $2,6 \pm 1,9$ respectivement). Les scores de l'EVS entre les groupes $F A, F B$, $F C S A$ et $S B$ ne different jamais. Aux doses étudiées, cette étude ne démontre pas l'effet antialgique préventif de l'administration systémique de fentanyl ou de sufentanil.

Analgesic strategies applied before the surgical stimulus may prevent the increase in excitability of the central nervous system and prevent or attenuate postoperative pain. ${ }^{1,2}$ However, the results of clinical studies comparing the effectiveness of an analgesic intervention made before surgery with the same intervention made after surgery 
are contradictory. Some studies demonstrate a better effect when an analgesic intervention like wound infiltration with local anaesthetic, ${ }^{3}$ epidural opioid, ${ }^{4}$ or intravenous morphine, ${ }^{5}$ are administered before than after surgery. Other studies demonstrate no effect of the timing of interventions, such as wound infiltration with local anaesthetic, ${ }^{6}$ epidural local anaesthetic and morphine, ${ }^{7}$ epidural bupivacaine, ${ }^{8}$ on postoperative pain.

The present study was designed to evaluate the influence of the timing of opioid analgesia and the related postoperative pain after total abdominal hysterectomy. We tested the hypothesis that fentanyl and sufentanil would be more effective in reducing postoperative pain when administered before induction of anaesthesia than after peritoneal incision or removal of the uterus.

\section{Methods}

With the approval from the Hospital Ethics Committee and informed consent, 85 unpremedicated women, ASA 1 and 2, scheduled for elective abdominal hysterectomy through a midline subumbilical incision were eligible for the study. Exclusion criteria were a history of chronic pain, regular intake of analgesic drugs, or a history of psychiatric disease.

Patients were numbered consecutively and assigned to one of the fentanyl (FA, FB, or FC), or sufentanil groups (SA or SB), according to a randomization schedule generated by a table of random numbers by means of a computerized statistical package (Statgraphics ${ }^{\circledR}$ ). The contents of a sealed envelope indicated the patient's group, determined by the opioid and the timing of its administration. The study was double-blind. Three syringes, one with fentanyl or sufentanil, and two with normal saline of equal volume as that containing opioid were prepared by an anaesthetist, who was involved in the patient randomization (opening of the envelopes) but not in its anaesthesia, pain assessment or data collection. All other anaesthetists, anaesthetic nurses and patients were unaware of the group to which the patient was assigned. Postoperative pain was assessed by an independent observer, who was not involved in patient randomization or anaesthesia administration.

Patients were assigned to groups FA and SA to receive: fentanyl $10 \mu \mathrm{g} \cdot \mathrm{kg}^{-1}$, sufentanil $1 \mu \mathrm{g} \cdot \mathrm{kg}^{-1}$ respectively five minutes before induction of anaesthesia, and an equal volume of normal saline after incision of peritoneum and after removal of the uterus. Those assigned to groups FB and SB received fentanyl $10 \mu \mathrm{g} \cdot \mathrm{kg}^{-1}$ or sufentanil $1 \mu \mathrm{g} \cdot \mathrm{kg}^{-1}$ respectively after incision of the peritoneum, and equal volumes of normal saline five minutes before induction of anaesthesia and after removal of the uterus. Group FC received fentanyl $10 \mu \mathrm{g} \cdot \mathrm{kg}^{-1}$ when the uterus was removed and equal volumes of normal saline five minutes before induction of anaesthesia and after incision of the peritoneum. A third sufentanil group with injection after removal of the uterus was not included, because in a pilot study we found this timing of sufentanil administration to delay extubation in some patients.

No opioid premedication was given and no other opioids were administered at induction intraoperatively except for the fentanyl and sufentanil as per the study protocol. After preoxygenation for three to four minutes, anaesthesia was induced with midazolam $0.1 \mathrm{mg} \cdot \mathrm{kg}^{-1}$, thiopentone $3-4 \mathrm{mg} \cdot \mathrm{kg}^{-1}$, vecuronium $0.1 \mathrm{mg} \cdot \mathrm{kg}^{-1}$, and maintained with $\mathrm{N}_{2} \mathrm{O}$ and isoflurane, inspired concentration $0.5 \%$ in $\mathrm{O}_{2}$, throughout surgery. Isoflurane administration was discontinued in all groups after closure of the peritoneum.

In the immediate recovery period no analgesics were given until patients asked for them. Pain at rest was assessed every $30 \mathrm{~min}$ after skin closure until the first analgesia request and $24 \mathrm{hr}$ later. The time to the first analgesia was recorded. Thereafter all patients received a standard analgesic regimen (propoxyphene $75 \mathrm{mg}$ with paracetamol $600 \mathrm{mg}$ im six hourly supplemented by meperidine $50 \mathrm{mg}$ given im $12 \mathrm{hr}$ postoperatively). For ethical reasons more analgesia was available to patients who might request it. However, none of our patients asked for additional analgesics to those prescribed by the clock.

In an attempt to assess pain better, particularly in the early postoperative period when some patients might have difficulty in cooperating, two pain scales were chosen and always administered in the same sequence. A self-rating method, the visual analogue scale (VAS), consisted of a $10 \mathrm{~cm}$ horizontal line with the zero point representing no pain and the $10 \mathrm{~cm}$ point representing worst pain, and a verbal rating scale (VRS) scoring pain intensity from $1=$ no pain to $6=$ intolerable pain were used All patients were given instructions in the use of VAS and VRS on the preoperative visit, the day after surgery.

\section{Data analysis}

Data are presented as the mean and standard deviation. Among the five groups significance was tested by oneway ANOVA to compare the demographic data, the duration of anaesthesia, and the time from skin closure to first analgesic request.

The VAS scores were analyzed for the five groups using a two-way repeated measurements ANOVA, and at each time point with one way ANOVA, including the five groups. The VRS scores were analyzed with the KruskallWallis test. A power analysis has also been performed.

\section{Results}

No differences were found with regard to the age, body weight and height of patients among the five groups. The 
TABLE I Demographic data and clinical variables of each group of patients

\begin{tabular}{lccccc}
\hline & $\begin{array}{l}\text { Fentanyl } \\
\text { before } \\
\text { induction } \\
(n=17)\end{array}$ & $\begin{array}{l}\text { Fentanyl after } \\
\text { peritoneal } \\
\text { incision } \\
(n=17)\end{array}$ & $\begin{array}{l}\text { Fentanyl after } \\
\text { removal } \\
\text { of uterus } \\
(n=17)\end{array}$ & $\begin{array}{l}\text { Sufentanil } \\
\text { before } \\
\text { induction } \\
(n=17)\end{array}$ & $\begin{array}{l}\text { Sufentanil after } \\
\text { peritoneal } \\
\text { incision } \\
(n=17)\end{array}$ \\
\hline Age (yr) & $45 \pm 9.4$ & $42 \pm 8.7$ & $41 \pm 10.5$ & $48 \pm 9.4$ & $46 \pm 10.9$ \\
Body weight (kg) & $71 \pm 12.1$ & $66 \pm 12.1$ & $64 \pm 10.4$ & $71 \pm 12.4$ & $67 \pm 10.8$ \\
Height (cm) & $160 \pm 4.3$ & $160 \pm 3.5$ & $163 \pm 6.3$ & $162 \pm 4.1$ & $161 \pm 6.1$ \\
Duration of anaesthesia (min) & $123 \pm 53.9$ & $121 \pm 61.2$ & $97 \pm 46.7$ & $146 \pm 75.0$ & $145 \pm 71.9$ \\
Skin closure to first analgesic (min) & $73 \pm 44.3$ & $85 \pm 80.5$ & $105 \pm 61.2$ & $58 \pm 35.7$ & $66 \pm 36.3$ \\
\hline
\end{tabular}

Mean \pm SD.

TABLE II Postoperative VAS pain scores in each group 30, 60, 90, 120, 150 min and $24 \mathrm{hr}$ postoperatively

\begin{tabular}{|c|c|c|c|c|c|}
\hline & $\begin{array}{l}\text { Fentanyl } \\
\text { before } \\
\text { induction }\end{array}$ & $\begin{array}{l}\text { Fentanyl after } \\
\text { peritoneal } \\
\text { incision }\end{array}$ & $\begin{array}{l}\text { Fentanyl after } \\
\text { removal } \\
\text { of uterus }\end{array}$ & $\begin{array}{l}\text { Sufentanil } \\
\text { before } \\
\text { induction }\end{array}$ & $\begin{array}{l}\text { Sufentanil after } \\
\text { peritoneal } \\
\text { incision }\end{array}$ \\
\hline $30 \mathrm{~min}$ & $\begin{array}{l}6.5 \pm 1.8^{a} \\
(n=11)\end{array}$ & $\begin{array}{l}5.1 \pm 2.3 \\
(n=12)\end{array}$ & $\begin{array}{l}3.2 \pm 2.5^{b} \\
(n=14)\end{array}$ & $\begin{array}{l}5.9 \pm 2.1^{c} \\
(n=14)\end{array}$ & $\begin{array}{l}4.5 \pm 2.0 \\
(n=12)\end{array}$ \\
\hline $60 \mathrm{~min}$ & $\begin{array}{l}4.4 \pm 1.6 \\
(n=7)\end{array}$ & $\begin{array}{l}3.5 \pm 2.1 \\
(n=10)\end{array}$ & $\begin{array}{l}3.9 \pm 2.6 \\
(n=13)\end{array}$ & $\begin{array}{l}4.6 \pm 1.6 \\
(n=5)\end{array}$ & $\begin{array}{l}4.3 \pm 2.9 \\
(n=7)\end{array}$ \\
\hline $90 \mathrm{~min}$ & $\begin{array}{l}3.8 \pm 0.9 \\
(n=3)\end{array}$ & $\begin{array}{l}2.2 \pm 1.0 \\
(n=5)\end{array}$ & $\begin{array}{l}3.1 \pm 2.1 \\
(n=8)\end{array}$ & $\begin{array}{l}4.7 \pm 1.4 \\
(n=4)\end{array}$ & $\begin{array}{l}4.0 \pm 2.1 \\
(n=5)\end{array}$ \\
\hline $120 \mathrm{~min}$ & $\begin{array}{l}6.1 \pm 1.5^{d} \\
(n=5)\end{array}$ & $\begin{array}{l}2.6 \pm 1.9^{e} \\
(n=5)\end{array}$ & $\begin{array}{l}4.1 \pm 1.8 \\
(n=8)\end{array}$ & $\begin{array}{l}5.7 \pm 0.8 \\
(n=2)\end{array}$ & $\begin{array}{l}4.1 \pm 1.2 \\
(n=3)\end{array}$ \\
\hline $150 \mathrm{~min}$ & $\begin{array}{l}4.6 \pm 0.8 \\
(n=2)\end{array}$ & $\begin{array}{l}3.4 \pm 1.9 \\
(n=4)\end{array}$ & $\begin{array}{l}3.8 \pm 2.4 \\
(n=4)\end{array}$ & & \\
\hline $24 \mathrm{hr}$ & $\begin{array}{l}4.0 \pm 2.1 \\
(n=17)\end{array}$ & $\begin{array}{l}4.3 \pm 2.2 \\
(n=17)\end{array}$ & $\begin{array}{l}3.4 \pm 1.8 \\
(n=17)\end{array}$ & $\begin{array}{l}3.8 \pm 1.9 \\
(n=17)\end{array}$ & $\begin{array}{l}3.7 \pm 1.9 \\
(n=17)\end{array}$ \\
\hline
\end{tabular}

Mean \pm SD.

${ }_{a . b}^{a-c}: P<0.003$, dee: $P<0.05$.

duration of anaesthesia, and the time elapsed from skin closure to the first analgesic did not differ among the FA, FB, FC, SA, and SB groups (Table I). None of the patients requested additional analgesia to those prescribed for the first $24 \mathrm{hr}$ postoperatively.

Since once a patient requested for analgesia she was no longer assessed for pain until $24 \mathrm{hr}$ later, the number of patients assessed at each $30 \mathrm{~min}$ interval postoperatively varied accordingly to the first analgesic request. An incomplete recovery $30 \mathrm{~min}$ postoperatively or even later prevented some patients from cooperating in pain assessment. The difficulty they had in responding to the VAS was greater than the VRS. This explains the missing data and the different numbers of patients assessed using the VAS and the VRS for the same time points (Tables II and III).

A difference of VAS score among the five groups was found with two-way repeated measurements ANOVA (F $=4.046$, df $=4,213, P<0.005$ ), group FC having a lower VAS score for all the measurements over the $24 \mathrm{hr}$ (3.52) than the FA group (4.95). At each time point, the one-way ANOVA with Bonferroni correction for multiple comparisons showed a difference at $30 \mathrm{~min}$ ( $\mathrm{F}=$ 4.542 , df $=4,58, P<0.003$ ). The VAS scores were higher in groups FA (6.5 \pm 1.8$)$ and SA (5.9 \pm 2.1$)$ than in the FC group (3.2 \pm 2.5$)$.

At $120 \mathrm{~min}$, the VAS scores were different $(F=3.217$ ), df $=4,18, P<0.05)$, being higher in the FA $(6.1 \pm$ 1.5) than in the FB (2.6 \pm 1.9$)$ group Table II).

The analysis of the VRS data, using the Kruskal-Wallis test showed no differences among the five groups at any time (Table III). A two factor power analysis showed that for sample size of 17 the power of the test was $>0.99677$.

\section{Discussion}

This study failed to show that opioid administration given before surgery results in reduced early postoperative pain compared with the same dose of the same opioid given after the surgical stimulus. These results apply to different opioids (fentanyl and sufentanil), and different timing of opioid administration (pre-incisional, after incision of the 
TABLE III Postoperative VRS pain scores in each group $30,60,90,120,150$ min and 24 hr postoperatively

\begin{tabular}{|c|c|c|c|c|c|}
\hline & $\begin{array}{l}\text { Fentanyl } \\
\text { before } \\
\text { induction }\end{array}$ & $\begin{array}{l}\text { Fentanyl after } \\
\text { peritoneal } \\
\text { incision }\end{array}$ & $\begin{array}{l}\text { Fentanyl after } \\
\text { removal } \\
\text { of uterus }\end{array}$ & $\begin{array}{l}\text { Sufentanil } \\
\text { before } \\
\text { induction }\end{array}$ & $\begin{array}{l}\text { Sufentanil after } \\
\text { peritoneal } \\
\text { incision }\end{array}$ \\
\hline $30 \mathrm{~min}$ & $\begin{array}{l}3.9 \pm 1.6 \\
(n=16)\end{array}$ & $\begin{array}{l}4.2 \pm 1.4 \\
(n=17)\end{array}$ & $\begin{array}{l}3.2 \pm 1.5 \\
(n=14)\end{array}$ & $\begin{array}{l}4.5 \pm 0.8 \\
(n=15)\end{array}$ & $\begin{array}{l}3.9 \pm 1.3 \\
(n=16)\end{array}$ \\
\hline $60 \mathrm{~min}$ & $\begin{array}{l}3.4 \pm 1.5 \\
(n=10)\end{array}$ & $\begin{array}{l}3.8 \pm 1.3 \\
(n=11)\end{array}$ & $\begin{array}{l}3.5 \pm 1.4 \\
(n=13)\end{array}$ & $\begin{array}{l}4.4 \pm 1.1 \\
(n=8)\end{array}$ & $\begin{array}{l}4.1 \pm 1.0 \\
(n=10)\end{array}$ \\
\hline $90 \mathrm{~min}$ & $\begin{array}{l}3.0 \pm 0.7 \\
(n=5)\end{array}$ & $\begin{array}{l}2.8 \pm 1.2 \\
(n=6)\end{array}$ & $\begin{array}{l}3.1 \pm 1.1 \\
(n=8)\end{array}$ & $\begin{array}{l}4.0 \pm 0.0 \\
(n=3)\end{array}$ & $\begin{array}{l}4.2 \pm 0.8 \\
(n=5)\end{array}$ \\
\hline $120 \mathrm{~min}$ & $\begin{array}{l}3.8 \pm 0.5 \\
(n=5)\end{array}$ & $\begin{array}{l}3.0 \pm 1.3 \\
(n=6)\end{array}$ & $\begin{array}{l}3.3 \pm 1.1 \\
(n=8)\end{array}$ & $\begin{array}{l}4.0 \pm 0.0 \\
(n=2)\end{array}$ & $\begin{array}{l}4.0 \pm 0.0 \\
(n=2)\end{array}$ \\
\hline $150 \mathrm{~min}$ & $\begin{array}{l}4.5 \pm 0.7 \\
(n=2)\end{array}$ & $\begin{array}{l}3.4 \pm 1.3 \\
(n=5)\end{array}$ & $\begin{array}{l}3.8 \pm 1.3 \\
(n=4)\end{array}$ & & \\
\hline $24 \mathrm{hr}$ & $\begin{array}{l}3.5 \pm 1.3 \\
(n=17)\end{array}$ & $\begin{array}{l}3.4 \pm 1.2 \\
(n=17)\end{array}$ & $\begin{array}{l}3.5 \pm 0.9 \\
(n=17)\end{array}$ & $\begin{array}{l}3.4 \pm 1.1 \\
(n=17)\end{array}$ & $\begin{array}{l}3.5 \pm 1.1 \\
(n=17)\end{array}$ \\
\hline
\end{tabular}

Mean \pm SD.

peritoneum or after removal of the uterus). On the contrary, VAS scores were found to be lower in group FC at $30 \mathrm{~min}$ than in the FA and SA groups, and lower in group FB at 120 min than in the FA group, suggesting that residual concentrations of the opioid rather than a preemptive effect contributed to postoperative analgesia.

Few controlled prospective studies have compared preoperative analgesic administration with analgesia given after the surgical stimulus. The analgesic intervention has been infiltration with local anaesthetic, field block, administration of local anaesthetic and/or opioid via an epidural catheter, regional block, or morphine given im/ $i v$. Preincisional lidocaine infiltration for elective inguinal herniotomy was found to be more effective in providing postoperative analgesia than postincisional infiltration. ${ }^{3}$ Extradural fentanyl has been reported to be more effective in reducing postoperative pain when given before than after skin incision. ${ }^{4}$ However, design flaws such as epidural lidocaine test dose, age differences between the two groups and preponderance of women in the preemptive group limit the validity of the results.

Caudal block in paediatric patients given before the onset or at the completion of surgery did not affect the duration of postoperative analgesia. ${ }^{9}$ Inguinal field block before or after hernia repair, ${ }^{6}$ continuous epidural infusion of bupivacaine and morphine before and after major abdominal surgery, ${ }^{7}$ and epidural blockade before or after abdominal hysterectomy, ${ }^{8}$ did not affect the immediate or late postoperative pain, whether block was given before surgery or at a later stage. These results are similar to ours. Richmond et al. showed that a small dose of morphine has a greater effect on analgesic requirements when given before rather than after the surgical stimulus. ${ }^{5}$ These results differ from ours. However, Richmond et al. ad- ministered the opioid at the time of closure of the peritoneum and assessed postoperative analgesic requirements using PCA, while we used a standard analgesic regimen and assessed the postoperative pain. We have chosen removal of the uterus as the late time point because the much higher equipotent doses of the opioid we administered than those used in the Richmond's study might delay tracheal extubation and proper communication in the early recovery period, if opioids had been given at closure of peritoneum.

The conclusions of the studies said to support or to refute preemptive analgesia are controversial. Some have design flaws, such as preoperative administration of an opioid, ${ }^{6-8}$ or extradural local anaesthetic test doses in all patients. ${ }^{4,7}$

Our data did not exclude a delayed preemptive analgesic effect, in the late postoperative period, beyond $24 \mathrm{hr}$. Nonetheless, in unmedicated volunteers pre-injury infiltration with lidocaine reduced hyperalgesia to pinprick and brushing outside the injury more effectively than the postinjury infiltration, but this effect was shortlasting. ${ }^{10}$ We did not measure the effect of timing of the systemic opioids on hyperalgesia. Abram and Olson have shown that systemic opioids do not suppress hyperalgesia that has been reported with intrathecal opioids. ${ }^{12}$

The validity of preemptive analgesia as a routine treatment strategy remains uncertain. Failure to reproduce the experimental results in clinical practice may be due to suppression of the preemptive effect by general anaesthesia. In clinical practice surgical stimulus always takes place during general anaesthesia, independent of whether opioids, NSAIDs, or local anaesthetics are administered before or after the surgical stimulus. One experimental study demonstrated that halothane antagonized the preemptive analgesia produced by $\mathrm{N}_{2} \mathrm{O}$ in rats. ${ }^{11}$ The pos- 
sible impact of isoflurane on the preemptive analgesia has not been investigated. A preemptive analgesic effect of lidocaine on thermal and mechanical hyperalgesia has been demonstrated in unmedicated volunteers. ${ }^{10}$

In conclusion, our results failed to show a preemptive effect of fentanyl or sufentanil but demonstrated, by VAS, that the duration of action of the analgesic was nearly constant, so that the preemptively administered analgesic had an earlier offset of action.

\section{References}

1 Dahl JB, Kehlet $H$. The value of pre-emptive analgesia in the treatment of postoperative pain. Br J Anaesth 1993; 70: 434-9.

2 Woolf $C J$, Chong $M-C$. Preemptive analgesia - treating postoperative pain by preventing the establishment of central sensitization. Anesth Analg 1993; 77: 362-79.

3 Ejlersen $E$, Andersen HB, Eliasen $K$, Mogensen $T$. A comparison between preincisional and postincisional lidocaine infiltration and postoperative pain. Anesth Analg 1992; 74: 495-8.

4 Katz J, Kavanagh BP, Sandler AN, et al. Preemptive analgesia: clinical evidence of neuroplasticity contributing to postoperative pain. Anesthesiology 1992; 77: 439-46.

5 Richmond CE, Bromley LM, Woolf CJ. Preoperative morphine preempts postoperative pain. Lancet 1993; 342: 73-5.

6 Dierking GW, Dahl JB, Kanstrup J, Dahl A, Kehlet H. Effect of pre- $v s$ postoperative inguinal field block on postoperative pain after herniorrhaphy. Br J Anaesth 1992; 68: 344-8.

7 Dahl JB, Hansen BL, Hjorts $\varnothing$ N, Erichsen CJ, Møiniche $S$, Kehlet $H$. Influence of timing on the effect of continuous extradural analgesia with bupivacaine and morphine after major abdominal surgery. Br J Anaesth 1992; 69: 4-8.

8 Pryle BJ, Vanner RG, Enriquez N, Reynolds F. Can preemptive lumbar epidural blockade reduce postoperative pain following lower abdominal surgery? Anaesthesia 1993; 48: 120-3.

9 Rice LJ, Pudimat MA, Hannallah RS. Timing of caudal block placement in relation to surgery does not affect duration of postoperative analgesia in paediatric ambulatory patients. Can J Anaesth 1990; 37: 429-41.

10 Dahl JB, Brennum J, Arendt-Nielsen L, Jensen TS, Kehlet $H$. The effect of pre- versus postinjury infiltration with lidocaine on thermal and mechanical hyperalgesia after heat injury to the skin. Pain 1993; 53: 43-51.

11 Goto T, Marota JJA, Crosby G. Nitrous oxide induces preemptive analgesia in the rat that is antagonized by halothane. Anesthesiology 1994; 80: 409-16.

12 Abram SE, Olson EE. Systemic opioids do not suppress spinal sensitization after subcutaneous formalin in rats. Anesthesiology 1994; 80: 1114-9. 